\title{
GROWTH OPPORTUNITIES AND EARNINGS QUALITY FROM EMERGING ECONOMIES
}

\author{
Kwarbai J.D. PhD. \\ Babcock Universit, Department of Accounting, Nigeria \\ Kwarbaij@babcock.edu.ng \\ Akintoye R.I. PhD. \\ Professorial chair for Chartered Institute of Taxation of Nigeria \\ at Babcock University, Nigeria \\ akintoyer@babcock.edu.ng \\ Adegbie F.F. PhD. \\ Head of Department of Accounting, Babcock University, Nigeria. \\ Adegbief@babcock.edu.ng \\ Nwaobia A.N. PhD. \\ Babcock University, Department of Accounting, Nigeria. \\ nwaobiaa@babcock.edu.ng
}

\begin{abstract}
We examined the causality between growth opportunities and earnings quality of the emerging economies. We develop an argument that growth opportunities should lead to high-quality earnings of the developing economies against the prior studies from developed economies which posit that growth opportunities result in a lower quality of earnings. The findings revealed that Growth Opportunities had a positive significant effect on Earnings Quality (EQ). Thus, the study concluded that growth opportunities are useful in determining the quality of earnings of corporates firms in Nigeria. The study recommends that managers should take advantage of their firms' growth opportunities to provide quality accounting information which will directly provide expanded opportunities for business growth. Though literature confirms that generally, earnings management might not be necessarily bad in business operational practice, managers are advised to avoid extreme aggressiveness in managing earnings as this may culminate into negative manipulation of accounting information.
\end{abstract}

Keywords: Earnings quality, Growth opportunities, Discretionary accruals, Corporate age, Corporate size. 


\section{Introduction}

Prior research in accounting and finance show that Growth opportunity is one of the factors considered in determining the survival or stability of the firm (Nwaobia, Kwarbai, Jayeoba \& Ajibade, 2016; Pranesh 2017). Firms with growth opportunities are more attractive to investors because of the higher potential for profits and capital appreciation/gains. Teoh and Wong (1993) haforocumented that the earnings response coefficient is positively related to growth opportunities. This further means that growth is an important phenomenon in every business. One of the basic assumptions of business is going concern that a business will continue to exist into a foreseeable future without threat to close down. Hence, their survival essentially depends on their power to participate in the market with other bigger companies (Akintoye 2008; Rauch \& Rijskik, 2013; Kwarbai, 2018). This implies that investors are more sensitive to information about growth opportunity firms.

Prior researches also suggest that firms that are not growing may be motivated to engage in aggressive earnings management to conceal their distress (Garcia, Gracia \& Neophytou, 2009; Li, Abeysekera \& Ma, 2011). On the other hand, Pranesh (2017) provides evidence that firms with growth opportunity have lower earning quality, signifying the fact that increasing the growth of a firm leads to an increase in the accounting choice exercised by the management while reporting the earnings figure. Managers of firms with relatively more investment opportunity set would have wider opportunity or more discretion to manage earnings. (Prihat, Zaki, Indra and Supriyadi, 2006).

It is frequently argued that high growth firms with lower asset value and higher future discretionary investment expenditure by managers are actually hard to observe and monitor; consequently, managers are more likely to engage in opportunistic reporting behaviour (Skinner, 1993); Skinner \& Sloan, 2002). We advance this debate through this study as we provide a view on the current state of the quality of earnings of firms with high growth opportunities in Nigeria, an emerging economy. Our study is related to so many works, but distinct from, prior studies that examine the effect of growth opportunities and earnings quality (Skinner, 1993; Ainajjar, \& Belkaoui, 2001; Pranesh, 2017). This study considers the level of firm's investment opportunity as condition that represents the opportunity to a wider practice of earnings management from developing nations. Based on our knowledge, there are no empirical papers which analyzed the relationship of growth opportunities and earnings quality in the Nigerian context. Hence, in this paper, we argue that growth opportunities do not improve the opportunistic behaviour of managers and reduces the quality of earnings but rather improves the quality of earnings. First, in determining earnings quality, we used the discretionary accrual to proxy earnings quality. Secondly, we analyzed the growth opportunities effect on earnings quality in the Nigerian financial market. Thirdly, we include corporate age and corporate Size to evaluate their moderating effect on the growth opportunities earnings management relationship.

The paper is organized into sections consist of this introduction. Section 2 Literature and theoretical underpinning, Section 3 explains the empirical methodology. Section 4, Results and findings. Discussion, the implication to research and Practice, conclusion and future research in section $5,6,7 \& 8$ respectively. 


\section{Literature/ Theoretical underpinning}

Information asymmetry could be relatively larger for firms with relatively more growth opportunities or investment opportunity set than firms with relatively more asset-in place. The greater the investment opportunity set, the more likely the firm will not be monitored as effectively as a firm with less investment opportunity set (Pranesh (2017). Firms with relatively more investment opportunity set, which largely comprised of intangible growth options more difficult to monitor, or less observable. On the other hand, if the firm is comprised largely of asset-in place it is relatively easy for an outsider to monitor. Thus the asymmetric information could be relatively larger for firms with relatively more investment opportunity set than firms with a relatively more asset-in place (Prihat, Zaki, Indra and Supriyadi, 2006; Ambarish et al., 1987; Skinner, 1993).

Pranesh (2017) studied the impact of a firm's growth and performance along with other control variables on earnings management in Indian non-financial firms for a period of nine years from 2007 to 2015. The empirical results provide evidence of a significant positive relationship between firm's growth opportunity and discretionary accruals signifying the fact that the increased growth of a firm may lead to an increase in the accounting choices exercised by the management while reporting the earnings figure. It is frequently argued that high growth firms with lower asset value and higher future discretionary investment expenditure by managers are actually hard to observe and monitor, consequently managers are more likely to engage in opportunistic reporting behaviour (Skinner, 1993); Skinner \& Sloan, 2002). Overall, the results show that a firm's growth potentiality and performance have important implications on the opportunistic behaviour by managers.

The value of a company is assessed based on its future growth opportunities and risks. Because of intense competition, management may be inclined to take higher risks to increase a company's market share and to promote the growth of performance. Myers and Turnbull (1977) stated that companies with more growth opportunities adopt a more conservative strategy in regards to the formulation of financial policies. However, growth opportunities cannot be realized to meet the market's dynamic challenges when the firms do not achieve their target of earnings (Roychowdhury, 2006). The study of McNichols and Stubben (2008) indicated that firms have a potential motivation to manipulate earnings to minimize distortions that occurred in the investment decisions that are simply dependent on the investors' expectations of future growth and product demand.

McNichols (2000) indicated that companies will use more accrual items on its earnings for enhancing future growth. The study of McNichols and Stubben (2008) stated that: "Expectations of future growth are based on information that includes revenues and earnings." Consequently, earnings misstatements are likely to influence the expectation of future growth. Jones (1991) model demonstrated that the variation in current sales revenues would be enough to capture the changes in the current accrual items. Prior research has compared companies that have lower expectations for future growth based on earnings and other companies that have higher expectations of their growth opportunities in terms of earnings.

Further, Cohen and Zarowin (2009 \& 2010) found that overinvestment firms or seasoned equity offerings firms actually engage in more earnings management activities. Wongsunwai (2012) 
also showed that external monitoring, and venture capitalist quality, affect firms' earnings management behaviour around initial public offerings. Chung (1993) found that when high growth opportunities and high risk existed simultaneously in a company, management tended to increase debt, which caused the company to lose growth opportunities to prevent bankruptcy.

The study of Richardson, Tuna, and Wu (2002) indicated that growing firms may attempt to report an increase in earnings by restating financial results. As a result, it is possible that management is likely to manipulate earnings for pursuing the growth target. On the other hand, AlNajjar and Riahi-Belkaoui (2001) showed that firms' growth opportunities affect net income and worth and thus produce political costs and risk. Therefore, firms with high growth opportunities and high risk might use income decreasing accruals.

Agency theory could explain the reason for corporate management use of accounting policies based on past experience and quality of earnings. However, Positive Accounting theory explains the different motives for using different accounting policies and it can explain the sign of the effect on the quality of earnings as affected by the growth opportunity of firms. Myers (1977) indicated the value of a company could be determined based on its future growth opportunities. However, companies with high growth opportunities also face more uncertainties, because the future values of a company primarily rely on $\mathrm{R} \& \mathrm{D}$ expenses, advertising and marketing expenses, talent recruitment, training expenses, et cetera. Although these expenses benefit a company's future growth, they are difficult to quantify in the current value of the company. Skinner and Sloan (2002) suggested that high levels of growth opportunities in a company might generate information asymmetry between the company and investors. Consequently, companies with higher growth opportunities are more likely to manipulate earnings to gain more benefits. Hence, this study hypothesized that,

\section{$\mathrm{H}_{01}$ : Companies with higher growth opportunities does not use discretionary accrual items to manipulate earnings.}

We draw upon prior research to identify other factors that can affect the causality of quality earnings and firms growth. We, therefore, include Corporate Age and Corporate Size to the model. According to Nwaobia, Kwarbai and Ogundajo (2016) Size and age variables could be used to control for the economic factors that influence a firm's growth.

\subsection{Methodology}

\subsection{Research Design, Sample and Data}

The ex-post facto research design was adopted in this study. Secondary data were extracted from the annual reports and accounts of twenty-six (26) companies for a period of 21 years (19962016) representing 546 firm-year observations. To achieve the objective of this paper, three variables were identified. The description and measurement of these variables are presented in section 3.3.

\subsection{Model Specification}


$\mathrm{AQUA}_{\mathrm{it}}=\alpha 0+\alpha_{1} \mathrm{GOOP}_{\mathrm{it}}+\alpha 2 \mathrm{CORPAGE}_{\mathrm{it}}+\alpha 3 \mathrm{CORPSIZEit}+\mu_{\mathrm{it}}$

where:

AQUA = accrual quality of the sample firms (used as proxy for earnings quality)

GOOP $=$ growth opportunity of firms

CORPAGE $=$ corporate age of the firms

CORPSIZE $=$ corporate Size of firms

\subsection{Measurement of Variables}

\subsubsection{Dependent Variable}

\section{Earnings Quality}

In determining the quality of earnings, we adopted the accrual quality model of Dechow and Dichev (2002) modified by McNichols (2002) and used by Kothari et al. (2005) and Nwaobia, Kwarbai, Jayeoba and Ajbade (2016), based on the unexplained accruals or residuals of the model, to estimate earnings quality of sampled firms. The residual value estimates the magnitude of the deviation from the expected level of investment. The deviation is captured by the positive or negative residuals from the expected accrual model and is denoted as the level of high and/or low earnings quality. The model adopted is mathematically presented as follows:

$\mathrm{TCA}_{\mathrm{it}}=\beta_{0}+\beta_{1} \mathrm{CFO}_{\mathrm{it}}-1+\beta_{2} \mathrm{CFO}_{\mathrm{it}-1}+\beta_{3} \mathrm{CFO}_{\mathrm{it}+1}+\beta_{4} \Delta \mathrm{REV}_{\mathrm{it}}+\mathrm{PPE}_{\mathrm{it}}+\varepsilon_{\mathrm{it}}$, scaled by Total Assets Where: $\mathrm{TCA}_{\mathrm{it}}=\left(\Delta \mathrm{CA}_{\mathrm{it}}-\Delta \mathrm{Cash}_{\mathrm{it}}\right)-\left(\Delta \mathrm{CL}_{\mathrm{it}}-\Delta \mathrm{STDBET}_{\mathrm{it}}\right)$

$\mathrm{TCA}_{\mathrm{it}}=$ Total Current Accrual: the firms' accruals in year $\mathrm{t}$, which AQUA???? the current assets change in year $t$ minus current liability changes, minus the changes of cash and cash equivalent year $t$ plus a change of short-term liability with interest in year $t$,

$\Delta \mathrm{CA}_{\mathrm{it}}=$ the change in current assets,

$\Delta \mathrm{Cash}_{\mathrm{it}}=$ the change in $\mathrm{cash} / \mathrm{cash}$ equivalents,

$\Delta C L_{i t}=$ the change in current liabilities,

$\triangle \mathrm{STDBET}_{\text {it }}=$ the change in short term debt.

$\mathrm{CFO}_{\text {it }}=$ represents the firms operating cash flow.

$\triangle \mathrm{REV}_{\mathrm{it}}=$ the change in revenue; while

$\mathrm{PPE}_{\mathrm{it}}=$ Property, Plant and Equipment

\subsubsection{Independent Variable}

\section{Growth Opportunity}

According to Raymond (2010), there are several measurements of growth opportunities in accounting and finance literature. These include Tobin's Q given as the market value of assets to the book value of assets, Dividend to share price ratio, research and development to sales ratio and Sales growth. In this study, we made use of a sales growth rate. Jones (1991) model 
demonstrated that the variation in current sales revenues would be enough to capture the changes in the current accrual items. According to Alonso et al (2005), growth opportunities within a firm are the realized growth. The study of McNichols and Stubben (2008) indicate that expectations of future growth are based on information that includes revenues and earnings. The expectation is that a high level of sales growth is related to a low quality of earnings. Hence, the expectation is that a firm with a high level of increasing sales has relatively more discretionary accruals. Therefore this paper expects a negative relationship between the sales growth rate and the quality of earnings.

\subsubsection{Control variables}

In this study, we used corporate age and corporate size of firms as control variables. While Corporate age (CORPAGE) was estimated as the absolute number of years of incorporation, Corporate Size (CORPSIZE) was estimated as a natural logarithm of total assets.

\section{Result / Findings}

Table 1 provides the descriptive statistics of the variables used in the study. It presents the mean, maximum, minimum and standard deviation. From the reported descriptive statistics, corporate age (CORPAGE), the age of the sampled firms used are within the range 10 years to 93 years of existence. This indicates that the firms under consideration are experienced in their respective areas of business endeavours due to the long duration of their corporate existence. Our thinking is that firms' age and experience in an industry may affect the quality of their reporting. There is also an indication that the firms under consideration have a large assets base (CORPSIZE) using $\log$ of the total asset as proxy. CORPSIZE has a minimum value of 4.036 billion and a maximum value of N10.14 billion suggesting that the firms are large firms. Firm size can influence reported earnings quality either way positively or negatively.

The descriptive statistics also indicate that growth opportunity (GOPP) has reported minimum value of -0.998 and a maximum of 999.00 . The reported mean and standard deviation values are 2.238 and 43.011 respectively. Thus, the minimum and maximum values as well suggest a broad variation away from the mean and as such the variable is volatile in nature.

For Accrual Quality (AQUA), standard deviations from the mean indicate a wide dispersion and this is supported by the minimum and maximum values of -103.667 and 483.40 respectively. 
Table 1

Descriptive Statistics

\begin{tabular}{cccccc}
\hline VARIABLE & OBS & MEAN & SD & MIN & MAX \\
\hline CORPAGE & 546 & 43.615 & 15.318 & 10.000 & 93.000 \\
CORPSIZE & 546 & 6.828 & 1.053 & 4.036 & 10.014 \\
GOPP & 546 & 2.238 & 43.011 & -0.998 & 999.000 \\
AQUA & 546 & 6.77 & 60.290 & -103.667 & 483.406 \\
\hline
\end{tabular}

Source: Researcher, 2018

\subsection{Diagnostic Tests}

Diagnostic tests were performed on the model to validate the correctness of model estimation. The result of the post estimation tests on Table 2 shows that all the various tests are significant with probability values of 0.000 , which is less than the acceptable 0.05 level of significance except hausaman test. Specifically, the significance of hausman test shows that the null hypothesis to estimate random effect should not be rejected; as such the model was tested for the appropriateness of random effect using the testparm option on Stata. The series indicated the presence of heteroskedasticity, first-order autocorrelation and cross sectional independence. Hence we used robust option to handle the presence of first-order autocorrelation and heteroskedasticity.

Table 2

Regression result

\begin{tabular}{|c|c|c|c|c|}
\hline VARIABLE & Coefficients & Std Error & t-Stat & Prob. \\
\hline $\bar{C}$ & 1.5682 & 0.0393 & 39.85 & $0.000^{*}$ \\
\hline CORPAGE & -0.8536 & 0.0351 & -24.34 & $0.000 *$ \\
\hline CORPSIZE & 0.5989 & 0.0812 & 7.37 & $0.000^{*}$ \\
\hline GOPP & 0.0406 & 0.0081 & 5.01 & $0.000^{*}$ \\
\hline R-squared & & 0.0522 & & \\
\hline Adjusted R-squared & & 0.0469 & & \\
\hline F-Statistic & & 9.95 & & \\
\hline Prob.(F-Stat) & & $0.0000^{*}$ & & \\
\hline Diagnostic tests & & Statistic & P-value & \\
\hline Hausman test & & 3.62 & 0.3055 & \\
\hline Breusch and Pagan $\mathbf{L M}$ test for random effects & & 1738.18 & $0.0000^{*}$ & \\
\hline Breusch-Pagan heteroskedasticity test & & 14.81 & $0.0001 *$ & \\
\hline Pesaran's test of cross-sectional independence & & -0.482 & 0.6295 & \\
\hline Wooldridge test for autocorrelation & & 18.460 & $0.0002 *$ & \\
\hline
\end{tabular}

Source: Stata 13 Output 


\section{Discussion}

Multiple regression estimates showed that the growth of sales as proxy for growth opportunities is significantly related to the level of discretionary accruals at a 5\% percent level. This means that the actual growth in sales is related to the level of discretionary accruals. This is a positive association. This is inconsistent with the A priori expectation that actual growth is negatively related to quality of earnings. This implies that company with higher growth opportunities is not more inclined to use discretionary accrual items to manipulate earnings.

Corporate Age exerted a negative effect while corporate Size had a positive effect on the quality of earnings. This is indicated by the sign of the coefficients, that is $\alpha_{1}=-0.8536<0$, and $\alpha_{2-3}=$ 0.5989 , and $0.0406>0$ respectively. This is indicative of the fact that companies can use the age and experience shield to act opportunistically and manipulate their earnings while the firm size could constrain such behavior in order to avoid reputational loss.

Additionally, the adjusted R-squared showed that 5\% variations in earnings quality proxy by accrual quality is caused by the use discretionary accrual items to manipulate earnings due to growth opportunities of the sample firm and the control variable of CORPAGE and CORPSIZE while the remaining 95\% variations in Accrual quality are caused by other factors not included in this model. Hence, the coefficient of determination shows that the model has an average explanatory power in explaining the variation seen in the accrual quality. This is further emphasized by the probability of the F-statistic of 0.000 which shows that the regression result is statistically significant because this is less than $5 \%$, the level of significance adopted for this study. Therefore, from the regression estimates, growth opportunities corporate age and corporate size of the firms jointly have a significant positive effect on the quality of earnings of firms in Nigeria.

\section{The implication to Research and Practice}

Our findings is consistent with our a priori expectation as we suggest that growth opportunities should lead to high-quality earnings in the developing economies against the prior studies from developing economies posit that growth opportunities result in a lower quality of earnings. Our study is inconsistent with the study of Beaver, (1968) that showed that growth opportunities provide managers with an incentive to smooth earnings as earnings volatility increase perceived firm risk which adversely affect the cost of capital needed by the firm. AlNajjar and RiahiBelkaoui (2001) showed that firms' growth opportunities affect net income and worth and thus produce political costs and risk. Richardson, Tuna, and Wu (2002) documented that growing firms may attempt to report an increase in earnings by restating financial results. As a result, it is possible that management is likely to manipulate earnings for pursuing the growth target and also is consistent with Pranesh (2017) that growth of the firm is positively associated with discretionary accruals and also indicate that firm's size and age were statistically significant influencing variables on the relationship of growth opportunities and earnings quality although our result indicate that corporate age exerts negative influence. The study implication is that managers should take the advantage of growth opportunities to provide quality accounting information which will directly provide expanded opportunities for business growth. As identified earlier that earnings management might not be necessarily bad in business operational 
practice but managers should avoid extreme aggressiveness which connotes negative manipulation of accounting information.

\section{Conclusion}

The study provided an insight into the causality between Growth opportunities and earnings quality in an emerging economy. Thus, the study concluded that growth opportunities are useful in determining the earnings quality of firms. Also, the controlling variable used in the models also affects the relationship between earnings quality and the firm's growth although depending on the association under consideration.

\section{Further Research}

We suggest in further research that proxy other than growth in sales should be used to capture growth opportunity to evaluate its impacts on financial reporting quality. 


\section{References}

Ainajjar, F., \& Belkaoui, A. R. (2001). Growth opportunities and earnings management. Managerial Finance, 27(12), 72-81.

Akintoye, I.R (2008). Optimizing investment decisions through informative accounting, European Journal of Social Science, 7(3), 178-191

Ambarish, R., K. John, and J. Williams, (1987). Efficient signalling with dividends and investments. Journal of Finance, 42, 321 -344.

Barton, J. (2002). Does the use of financial derivatives affect earnings management decisions? The Accounting Review, 76(3), 1-26.

Bose, I. and R. Pal (2012). Do green supply chain management initiatives impact stock prices of firms? Decision Support Systems, 52, 624-634.

Gaiso, C., \& Raposo, C. (2011). Earnings quality and firms valuation: International evidence. Accounting and Finance, 51(2), 467-499.

Garcia L. J., Garcia O, B. \& Neophytou, E. (2009). "Earnings quality in ex-post failed firm". Accounting and Business Research, 39(2), 119-138.

Healy, P. M., \& Palepu, K. G. (1993). The effect of firms' financial disclosure strategies on stock prices. Accounting Horizons, 7(1), 1.

Jones, J.J. (1991). Earnings management during import relief investigations, Journal of Accounting Research, 29 (2) 193-229.

Kwarbai J.D (2018). Financial Reporting Quality and Business growth of Manufacturing firms in Nigeria. $\mathrm{PhD}$ thesis (Unpublished)

Li, F.; Abeysekera, I. \& Ma, S. (2011). "Earnings management and the effect of earnings quality in relation to stress level and bankruptcy level of Chinese listed firms". Corporate Ownership and Control, 9(1), 45-68

McNichols, M. and S. Stubben (2008). Does Earnings management Affect Firms' Investment Decisions, The Accounting Review, 1571-1603.

Myers, S. (1977). Determinants of Corporate Borrowing, Journal of Financial Economics, 5, pp. 147-175.

Nwaobia A.N, Kwarbai J.D, Jayeoba O.O, and Ajibade A.T (2016). Financial reporting Quality and investors decision. International Journal of Economics and Financial Research. 2(7)140147

Nwaobia, A. N., Kwarbai, J. D. and Ogundajo, G. O. (2016). Tax planning and firm value: Empirical evidence from Nigerian consumer goods industrial sector. Research Journal of Finance and Accounting 7(2). 172-183 
Pranesh Debnath (2017). Assaying the Impact of Firm's Growth and Performance on Earnings Management: An Empirical Observation of Indian Economy. International Journal of Research in Business Studies and Management. 4( 2) 30-40

Prihat A. Zaki B. Indra W. and Supriyadi G. (2006). The Effect Of Investment Opportunity Set On The Association Between Incentives And Earnings Management Level. The International Journal of Accounting and Business Society 14 1-10.

Raymond P. (2010). The relation between growth opportunities and earnings quality: A crosssectional study about the quality of earnings for European firms with relatively high growth opportunities. Review of Quantitative Finance and Accounting. 1-19

Richardson, S., I. Tuna and M. Wu (2002). Predicting Earnings Management: The Case of Earnings Restatements, Working paper, University of Pennsylvania

Schipper, K. and Vincent, L. (2003). Earnings quality”, Accounting Horizon, 17, (Supplement), 97-111.

Shaio Y, Yu-Hsuan Chung, An-An Chiu and Yu-Cheng Chen (2015). Growth opportunity and risk: an empirical investigation on earnings management decision. Investment Management and Financial Innovations, 12(1-2), 299-309

Skinner, D. J., \& Sloan, R. G. (2002). Earnings surprises, growth expectations, and stock returns or don't let an earnings torpedo sink your portfolio. Review of accounting studies, 7(2-3), 289312.

Skinner, D.J., (1993), "The Investment Opportunity Set and Accounting Procedures Choice: Preliminary Evidence." Journal of Accounting and Economics 16. 407-445.

Teoh, S. H., \& Wong, T. J. (1993). Perceived Auditor Quality and the Earnings Response Coefficient. The Accounting Review, 68(2), 346-366.

Watts R., \& Zimmerman J., (1986). Positive Accounting Theory, Prentice-Hall, Inc. Englewood Cliff 